\title{
The Use of Wastewater in the Irrigation of Agricultural Soils and its Contamination Effect by Trace Elements: A Review
}

\author{
Kerboua Faycal, MA \\ Laboratory of Biology and Environment, \\ University of Constantine 1, Algeria
}

Doi: 10.19044/esj.2018.v14n18p273 URL:http://dx.doi.org/10.19044/esj.2018.v14n18p273

\begin{abstract}
Wastewater reuse (either raw or treated) for irrigation of crops is a common widespread practice around the world. This water provides the soil with many nutrient elements. However, it also results to organic and metallic contaminants. This may have a significant effect on the physico-chemical characteristics of the soil and the crops contamination. It is a fact that constitutes a huge risk which is both sanitary and environmental. This paper focuses on explaining the effect of the use of wastewater in the irrigation of the agricultural soils and crops and their contamination by trace elements.
\end{abstract}

Keywords: Wastewater, trace elements, soil, irrigation

\section{Introduction}

Water demand is remarkably increasing in many countries around the world for various reasons like the growth of populations, the economy's prosperity, and the improvement of living standards. One of the most demanding fields, however, is agriculture, since it makes use of $67 \%$ of total water withdrawal which represents $86 \%$ of water consumption in 2000 as reported by UNEP (2005). According to the Food and Agriculture Organization, 277 million hectares of lands are irrigated out of 1.4 billion hectares of arable ones, which provides one-third of the world's food production (Gurel, 2007).

Using wastewater for irrigation is a considerably widespread practice in developing countries (Raschid-Sally et al., 2005; Scott et al., 2004). This can be explained particularly in terms of the demographic growth. Hence, this can also be seen due to an increase in water consumption per capita that leads consequently to a high quantity of wastewater production in both urban and rural areas. On the other hand, the high demand for food shows the need for a reliable irrigation practice to maintain or enhance the rate of food production, 
especially in the warm climate regions. $80 \%$ out of the 53 studied towns in Africa, Asia, South America and Middle East use the untreated wastewater or the partially treated one for irrigation (Raschid-Sally et al., 2009).

The reuse of wastewater (either raw or treated) in agriculture is a means to fix the growing problem of water scarcity in many arid and semiarid countries and to face the climate change at a global scale. Despite the fact that it represents an important low-cost source of water compared to other sources (Bahri, 1999), it constitutes of a regular and permanent irrigation water source (Murtaza et al., 2008). This phenomenon is also expanding in many countries with the temperate climate like Japan, Australia, Canada, Belgium, England, and Germany (Gurel, 2007).

According to an investigation made in 2001, the total surface of irrigated lands by wastewater, either the treated or the partially treated ones, was estimated to be around 20 million hectares (Hamilton et al., 2007). As far as wastewater irrigation expansion is concerned, the recently obtained estimates (Thebo et al., 2017) demonstrates that the scale of the practice is at least $50 \%$ larger than previous, highly uncertain estimates. Thus, the result shows that $10 \%$ of the world's population consumed food produced in lands irrigated with wastewater during the early 90's (Smit \& Nasr, 1992).

The use of wastewater in irrigation is more and more regarded due to the lower cost technical solutions for decreasing soils degradation, and also for intoducing new nutrient elements into the soil (Kiziloglu et al., 2008; Yadav et al., 2002; Xiong et al., 2001).

\section{Consistence of Trace Elements in Wastewater}

One of the major problems that both the developed and the developing countries are suffering from is water pollution which is caused by the pollution of wastewater by trace elements pollutants. Urban effluents always consist of the trace elements (Smith et al., 1996; Pescod, 1992). These trace elements have very high quantity that is largely superior to what potable water, rivers water, or sea water are supposed to contain (Juste et al., 1995). The most abundant ones are cadmium $(\mathrm{Cd})$, copper $(\mathrm{Cu})$, molybdenum $(\mathrm{Mo})$, nickel (Ni), and zinc $(\mathrm{Zn})$, which are all dangerous to the health of humans and animals; in addition, it can also affect, in the long-term, the irrigated crops due to their accumulation in the soil (Hamilton et al., 2007).

Trace elements content in wastewater differs from one another depending on its origin and the nature of urban activities (Smith et al., 1996; Rattan et al., 2005). Generally, the trace elements in commercial and industrial wastewater is much more superior than that noticed in the domestic one (Smith et al., 1996; Juste et al., 1995). 


\section{The Effects of Wastewater Irrigation on Soils Agronomic Properties}

It is quite obvious that the quality of the soil depends on their intrinsic characteristics, the geo-chemical and climatic environment, and man's use (Arshad \& Coen, 1992). As a result, the quality of the irrigating water frequently used affects the physico-chemical properties of the soil.

\section{pH}

Almost all authors agree that soils $\mathrm{pH}$ depends on wastewater $\mathrm{pH}$ used for irrigation (Khan et al., 2008; Yadav et al., 2002; Kiziloglu et al., 2008; Qichlaqi et al., 2008). Many authors noticed that there is a decrease in the $\mathrm{pH}$ of the soil after being irrigated with wastewater (Chary et al., 2008; Rattan et al., 2005; Shahalam et al., 1998; Solis et al., 2005) (Table 1). Rattan et al. (2005) registered a significant decline of 0,4 units, while Shahalam et al. (1998) and Kiziloglu et al. (2008) registered a decline of 0,6 units. Furthermore, using a slightly acid water for irrigation would not have any significant effect on the variation of soils pH (Khan et al., 2008; Sinha et al., 2006). The $\mathrm{pH}$ decrease may be caused, on the one hand, by a release of exchangeable cations during a process of an organic material mineralization brought by wastewater (Kiziloglu et al., 2008). On the other hand, the supply with wastewater may reduce the content of active limestone (responsible for the alkalinity) in those soils (Solis et al., 2005).

Table 1. pH evolution of soils irrigated by wastewater

\begin{tabular}{|l|l|l|l|}
\hline \multicolumn{1}{|c|}{ References } & \multicolumn{3}{c|}{$\mathrm{pH}$} \\
\cline { 2 - 4 } & \multicolumn{1}{|c|}{$\begin{array}{c}\text { Irrigation } \\
\text { sewage }\end{array}$} & \multicolumn{1}{c|}{ Bearing soil } & $\begin{array}{c}\text { Soil irrigated by } \\
\text { Wastewater }\end{array}$ \\
\hline (Shahalam et al., 1998) & 8.6 & 8.4 & 7.7 \\
(Yadav et al., 2002) & 7.4 & 8.5 & 8.1 \\
(Rattan et al., 2005) & $5.8-6.5$ & 7.9 & 7.5 \\
(Khan et al., 2008) & $/$ & 8.0 & 7.9 \\
(Kiziloglu et al., 2008) & 8.55 & 7.52 & 6.85 \\
(Madyiwa et al., 2002) & $/$ & 4.6 & 5.4 \\
(Sinha et al., 2006) & 7.26 & 8.16 & 8.26 \\
(Al-nakshabandi et al., 1997) & 7.4 & 7.9 & 8.1 \\
(Qishlaqi et al., 2008) & $8.4-9.8(9)$ & 7.29 & 8.6 \\
\hline
\end{tabular}

Some authors, had reported that the soils $\mathrm{pH}$ had significantly increased due to the irrigation with wastewater (Madyiwa et al., 2002; Qishlaqi et al., 2008; Al-nakshabandi et al., 1997) (Table 1) reaching 1.3 unit as it was shown in the study of Qishalaqi et al. (2008). However, this is caused by the basic nature of wastewater used for irrigation ( $\mathrm{pH}$ average 9). The latter which is loaded with basic cations is responsible for soils alkalization (Madyiwa et al., 2002). The $\mathrm{pH}$ increase may reflect the lime nature of the mother rock, even if a weak dissociation of $\mathrm{CaCO}_{3}$ may increase the $\mathrm{pH}$ too. 
In addition, limestone soils buffer effect may prevent soil acidification, and hence keep the soils pH neutral (Chen et al., 2007).

\section{Soil Organic Matter Content}

Irrigation using wastewater leads to an increase of soil's organic matter content and thus contributes to its fertility (Rattan et al., 2005; Yadav et al., 2002; Qishlaqi et al., 2007; Lucho-Constantino et al., 2005). The rate of enrichment may vary according to the content of organic matter in wastewater. Within 20 years, Rattan et al. (2005) and Qishlaqiet al. (2008) have estimated the enrichment of the surface horizons of irrigated soils between 20 and $60 \%$ varying according to the nature of the soil itself. The duration of irrigation seems to be positively effective based on the organic matter content (LuchoConstantino et al., 2005).

\section{Soil Salinity}

Generally speaking, wastewater salinity (salt concentration) varies according to its origin. Industrial wastewater salinity is much higher than the one of municipal wastewater (Hamilton et al., 2007). The physical and mechanical properties of the soil just like the particle dispersion, aggregate stability, and soil permeability and its structure are very reactive to the nature of ions present in irrigation water (Pescod, 1992). Salts accumulation in the superior horizons of soil presents a high risk of the spreading of wastewater (Duan et al., 2010). Solis et al. (2005) has noticed that long term irrigated soils with wastewater consisted of an important accumulation of salt (mainly in $\mathrm{Na}$ ).

In general terms, the reuse of water in irrigation must have a weak or an average degree of salinity (electricity conductivity should be between 600 and $1700 \mathrm{~cm}^{-1}$ ) according to Feigin et al. cited in Hamilton (2007). However, wastewater frequently exceeds the precedent value (Al-nakshabandi et al., 1997; Yadav et al., 2002; Biggs \& Jiang , 2009; Murtaza et al., 2008; Sinha et al., 2006), which presents a big salinity risk to soils irrigated with this water. Biggs and Jiang (2009) recorded an increase in electricity conductivity ranging between 6,2 to 8,4 times superior to one of soils irrigated with underground water.

\section{CEC and Exchangeable Cations}

Wastewater usually increases cations exchange capacity. This is explained mainly in terms of an influx of organic matter and exchangeable cations (Hamilton et al., 2007; Qishlaqi et al., 2008; Biggs \& Jiang, 2009). Irrigation using wastewater enhances the concentration of exchangeable cations ( $\mathrm{Na}, \mathrm{K}, \mathrm{Ca}, \mathrm{Mg}$ ) and available trace elements. It was calculated that a blade of residual water of $100 \mathrm{~mm}$ may bring to a hectare amounts varying from 16 to $62 \mathrm{~kg}$ of nitrogen, from 2 to $69 \mathrm{~kg}$ of potassium, from 4 to $42 \mathrm{~kg}$ of 
phosphorus, from 18 to $208 \mathrm{~kg}$ of calcium, from 9 to $100 \mathrm{~kg}$ of magnesium, and from 27 to $182 \mathrm{~kg}$ of sodium (Faby \& Brissaud, 1997).

Wastewater spreading causes exchangeable cations accumulation in arable layers (Hamilton et al., 2007). Qishlaqi et al. (2008) recorded an important quantity of $\mathrm{Ca}$ in the arable layer (higher than $2500 \mathrm{mg} \cdot \mathrm{kg}^{-1}$ ). Biggs and Jiang (2009), on the other hand, have noticed an accumulation of $\mathrm{Na}$ cations, which is an average of 20 to 22 times superior compared to lands irrigated with underground water. This latter causes soils sodisation (a high $\mathrm{Na}^{+}$proportion comparing to soils $\mathrm{Ca}^{2+}$ and $\mathrm{Mg}^{2+}$ ), which in return leads to the destruction of the soil structure by the dispersion of clay aggregates (Agassi et al., 2003). This, therefore, is a fact that explains the decrease in permeability and porosity of soils' superficial layers (Faby \& Brissaud, 1997).

Soils' cations composition differs according to wastewaters cations and the sites of soils exchange. An example is $\mathrm{Mg}^{2+}$ and $\mathrm{K}^{+}$cations which are connected more to clay fraction compared to $\mathrm{Na}^{+}$cations (Biggs \& Jiang, 2009).

\section{Trace Elements Concentrations in the Soil}

The spreading of raw wastewater is potentially dangerous to soils because of its consistency in the transportation of toxic elements like trace elements. This is because wastewater is considered to be the main source of anthropogenic trace elements in the soil. Using it for irrigation constitutes an important source of trace elements for the soils too. Even if many authors reported that wastewater irrigation does not cause a significant trace elements accumulation in the surface horizon (Cebula,1980; Ramirez-Fuentes et al., 2002), there are, however, many noticed cases of contamination by trace elements (Xiong et al., 2001; Schirado et al., 1986; Schalscha \& Ahumada, 1998; Jiries et al., 2002; Flores et al., 1997; Chen et al., 2007; Wu \& Cao, 2010). Long term irrigation with municipal effluent water increases the soils metal concentrations (Schirado et al., 1986; Sharma et al., 2007; Flores et al., 1997; Chary et al., 2008; Wu \& Cao, 2010). Qishlaqi et al. (2007) have noticed a high concentrations of lead $(\mathrm{Pb})$ in the arable layer caused mainly by the high value of organic matter. According to Alloway (1995), if any soil that is exposed to an important value of organic matter is brought either by wastewater or mud, the organic matter is going to be as a source of both organic and inorganic pollutants (trace elements). Also, it is going to be a major absorbent of contaminants. In many investigations, it had been proved, however, that there is a positive correlation between the organic matter and metals present in the soil (Qishlaqi et al., 2008; Flores et al., 1997). 


\section{Evolution of Trace Elements Concentration according to the Depths}

Irrigation using wastewater increases trace elements concentrations in the superior horizons of soils (Flores et al., 1997; Mutraza et al., 2008; Dère, 2006; Qishlaqi et al., 2007; Sharma et al., 2007). Dère (2006) has reported that after 100 years of experiences, the use of raw wastewater in irrigation led to an increase in trace elements contents exogenously of $98 \%$ out of the total content of surface horizons (plowed ones). In the investigation led by Flores et al. (1997) which was about irrigation of soils with raw wastewater, they noticed an important accumulation of trace elements in the surface horizons between $0-10 \mathrm{~cm}$. This corresponds to an enrichment varying between 31 and $49 \%$ for $\mathrm{Cd}, 14$ and $73 \%$ for $\mathrm{Pb}$, and between 21 and $55 \%$ for $\mathrm{Zn}$ compared to the beneath horizons $(50-60 \mathrm{~cm}$ depth). For the most profound horizons, the enrichment is much more important (90-100 cm depth), varying between 49 and $144 \%$ for $\mathrm{Cd}, 19$ to $587 \%$ for $\mathrm{Cu}, 100$ to $418 \%$ for $\mathrm{Pb}$, and between 31 and $120 \%$ for $\mathrm{Zn}$.

Thus, according to Ayers and Westcot (1994), more than $85 \%$ of trace elements, brought by wastewater used for irrigation, was accumulated in the surface horizon of the soil.

Dère (2006) reveals, in her study about the pollution of sandy Luvisols in Parisian region after 100 years of an intensive irrigation with wastewater, that there is an important migration of $\mathrm{Ni}, \mathrm{Zn}, \mathrm{Cu}$, and $\mathrm{Cd}$ towards the depths $(40-100 \mathrm{~cm})$. She even observed that exogenous stocks (brought by raw wastewater) in this horizon represents $45 \%$ for $\mathrm{Ni}, 31 \%$ for $\mathrm{Zn}, 14 \%$ for $\mathrm{Cu}$, and $10 \%$ for Cd out of Exogenous stock of ETM present in the solum. Metal infiltration and leaching in the depth are two procedures that leads to the contamination of underground water (Li et al., 2003). 2006):

In general, ETM migration to the depth depends mainly on (Dére

- The Considered Elements $(\mathrm{Zn}, \mathrm{Pb}, \ldots)$ : Trace elements mobility depends on their form in a solution, which controls their similitude with the horizon constituents of the soil. $\mathrm{Zn}$ and $\mathrm{Ni}$ occur predominantly in a cationic form, where the $\mathrm{Cu}$ is in cationic form or forming a complex element with a dissolved organic matter. Qishlaqi et al. (2007) have noticed that $\mathrm{Pb}$ is less mobile and this is what causes its accumulation in the arable (surface) layer. Also, it matches and corresponds to Dére's study, in which she observed a total absence of exogenous $\mathrm{Cr}$ and $\mathrm{Pb}$ under plow horizon $(0-40 \mathrm{~cm})$ on the opposite of $\mathrm{Ni}, \mathrm{Zn}, \mathrm{Cu}$, and $\mathrm{Cd}$ that migrate to the solum depth. Fitamo et al. (2007) have investigated the two kinds of soils (Fluvisol and vertisol) in the region of Adis Ababa, and noted that $\mathrm{Zn}$ is a little mobile in vertisol soil, while $\mathrm{Cr}$ is a little mobile in both soils.

- Chemical Characteristics of Soil Horizons: The most important obstacles for trace elements are the organic matter, carbonates, clayey 
minerals, and iron and manganese oxyhydroxides. It seems that trace elements brought by wastewaters are fixed by the organic matter (Qishlaqi et al., 2007; Flores et al., 1997; Dère, 2006).

- Physical Properties of Soil Horizons (Structure, Permeability): In Dére's investigation (2006), the content of $\mathrm{Zn}$ in the sandy clay horizon is related to the horizon's permeability.

- Hydraulic function of the soil constitute a non-negligible fact in the redistribution of trace elements exogenous in the inferior horizons (Dère , 2006).

\section{Evolution of Trace Elements Concentration through Time}

Many investigations have shown a linear connection between the content of the soil and the period of time of irrigation with wastewater (LuchoConstantino et al., 2005; Flores et al., 1997; Dére, 2006; Xiong et al., 2001).

Trace elements accumulation is a common phenomenon noticed also in soils irrigated with water in which the average of trace elements does not exceed the one of water predestined for irrigation (Rattan et al., 2005).

Based on the concentration of trace elements and the amount of irrigation water used yearly, Murtaza et al. (2008) have estimated that wastewater irrigation causes an annual input of an area between 0.88 and $0.96 \mathrm{~kg} \mathrm{ha}^{-1}$ for cadmium. With such an input, the studied samples of soils reach the limited threshold requested of trace elements content in agricultural soils after a decade of irrigation.

Assadian et al. (1998), on the other hand, have estimated that after 50 years of irrigation with wastewater, trace elements' intake is $10 \mathrm{~kg} \mathrm{ha}^{-1}$, which represents $31 \%$ of surface soils metals charge.

\section{Location of Trace Elements in Soils Irrigated with Wastewater}

Flores et al. (1997) investigation on the chemical fraction, shows that the mobile and exchangeable fractions do not exceed 4,5\% of metal stock. On the other hand, dominant fractions are the organic and carbonate ones, to which $\mathrm{Pb}$ is more connected to $71 \%$. This is followed by the other metals $(\mathrm{Cd}$, $\mathrm{Zn}, \mathrm{Cu}$ ) with an average varying between 42 and 46\%. The Organic fraction is the most important for the following four trace elements, $\mathrm{Cu}$ (between 14 and 65\%), $\mathrm{Cd}$ (between 20 and 46\%), $\mathrm{Pb}$ (between 34 and 52\%), and $\mathrm{Zn}$ (between 16 to $61 \%$ ).

Fitamo et al. (2007) have noticed that almost all metals are mainly connected to the non-risidual fraction, whereas $\mathrm{Zn}$ and $\mathrm{Cr}$ are connected to the residual fraction (non labile). According to Dére's study (2006), Zn was the only metal to connect with the exchangeable fraction with an important proportion of $20 \%$ in the plow horizon, probably explained in relation to its form. Hence, it is the form and the nature of the metal, in addition to the soils 
properties (physical, chemical, biological and mineral), that determine trace elements mobility and availability in the non-residual fractions (Fitamo et al., 2007).

Chen et al. (2007) have reported that after 25 years of suspension of irrigation using wastewater, $\mathrm{Zn}$ is connected to the reducible fraction (iron oxide) followed by the residual fraction. On the other hand, mobile, exchangeable, and carbonate fractions represent $50 \%$ of $\mathrm{Cd}$ total stock. For Fitamo et al. (2007), Cd, Cu, $\mathrm{Zn}$, and $\mathrm{Pb}$ are all connected mainly to reducible and carbonate fractions.

Generally, chemical speciation studies of irrigated soils with wastewater, all indicate and reveal that trace elements are found in a moderately mobilisable form.

\section{Availability of Trace Elements}

Trace elements passage through the soils solution is controlled by the form (speciation) under which they are during the solid phase: exchangeable, absorbed, forming a complex with the surface constituents of the soil, or coprecipitated. Organic matter, carbonates, clay minerals, and iron and manganese oxy-hydroxid are the main constituents involved in trace elements retention (Adriano et al., 2004). Trace elements, routed in the soil via wastewater, would not all have an assimilable or bioavailable forms, but their chemical form will depend also on the intrinsic conditions of the soil like the $\mathrm{pH}$, Eh, the organic matter, the clay rate, the cation exchange capacity CEC, and the total organic carbon TOC (Solis et al., 2005).

Many authors have observed that $\mathrm{Cd}$ phytoavailability depends on the soil physicochemical properties more than its total concentration in the soil. On the other hand, exchangeable $\mathrm{Ca}$ brought by wastewater contributes in the insoluble complex formation of $\mathrm{Pb}$ in the arable layer, which reduces its availability in the soil's solution. This, inturn, explains the negative relation between $\mathrm{Ca}$ exchangeable content and $\mathrm{Pb}$ availability (Qilshaqi et al., 2008). A continuous supply of nitrogen by wastewater may contribute in the enhancement of the bioavailability and plants' absorption of trace elements (Sharma et al., 2007).

Trace elements high concentration in the soils does not necessarily means their phytoavailibility (Liu et al., 2005). Furthermore, Qishlaqi et al. (2008) have observed that only 1,3 to $7,7 \%$ and 0,07 to $1,69 \%$ of $\mathrm{Pb}$ total content and $\mathrm{Ni}$ are phytoavailable due to the combined effect of the organic matter (fixing) and the alkaline pH. The study led by Chary et al. (2008), executed on the soil alongside of Musi river (India), have demonstrated that 70 to $77 \%$ of lead is connected to non-mobile fractions because of the high content of these soils with the organic matter brought by wastewater. 
Generally speaking, an alkaline soil that is superior to 8 is known to limit trace elements mobilization, hence reducing their absorptions (Sharma et al., 2007). Trace elements availability enhances with the raise of soil acidity. Indeed, trace elements concentration in plants is negatively correlated with solution pH (Adams et al., 2004; Qilshaqi et al., 2008). pH increase reduces the absorption and concentration of $\mathrm{Cd}$ in the leaves of lettuce (Xue \& Harrisson, 1991) and also the one of colza (Eriksson, 1989) and other farmings. The combination of a high $\mathrm{pH}$ level, the organic matter, and limestone may decrease the trace elements phytoavailability (Murtaza et al., 2008). For Qilshaqi et al. (2008), it depends mostly on the physicochemical properties of the soil rather than their total concentration in the soil. Nevertheless, a high rate of water nutritious elements may lead to a relatively high rate of growth, which results in a sample relatively rich of trace elements (Sharma et al., 2007; Qilshaqi et al., 2008).

Among the set of trace elements, Cadmium is considered to be the most health threatening metal due to wastewater irrigation. Largely available to plants, situated with high concentrations in plants edible parts, it is very dangerous to man (Hamilton et al., 2007; Mapanda et al., 2007). On the other hand, Zaranyika et al. cited in Mapanda et al. (2007) have proved that $\mathrm{Cu}^{2+}$ has a good affinity with the organic matter and it easily form complexes, and thus reduces its availability for plants.

In Sharma et al. (2007) study, the sample of $\mathrm{Cd}, \mathrm{Zn}, \mathrm{Cr}$, and Mn was more important during summer season. This is a fact explained mainly in relation to a release of trace elements after the relatively high decomposition of organic matter (McGrath et al., 1994) and also the high rate of plants transpiration (Ingwersen \& Streck, 2005).

Mobility and availability of trace elements are controlled by numerous chemical and biochemical processes as dissolution-precipitation, adsorptiondesorption, complex formation-dissociation, and the oxydoreduction. Each process depends on the reactions of soil and the rhizosphere effect (He et al., 2005).

\section{Content of Trace Elements in Plants}

The transfer of trace elements to plants irrigated with wastewater may cause trace elements accumulation in plants' tissues, and in some cases, the content of these metals may reach phytotoxicity thresholds (Faby \& Brissaud, 1997). In many cases, plants content of trace elements exceeds by large its content in control plants or guideline concentration as denoted by Xiong et al. (2001), Mapanda et al. (2007), Yadav et al. (2002), Qishlaqi et al. (2008), Sharma et al. (2007), Rattan et al. (2005), and Chary et al. (2008). 
According to the references, the most irrigated plants with wastewater are vegetables which accumulate the large amount of trace elements in their tissues (Sharma et al., 2007; Sinha et al., 2006).

Despite the physiological characteristics of plants, the heavy metal content incultures depends also on the physical and chemical nature of the soil, which controls the bioavailability of trace elements. This later depends on many facts like: soil temperature, moisture, organic matter, $\mathrm{pH}$, and nitrogen availability (Sharma et al., 2007; Qishlaqi et al., 2008). Many investigations have denoted that a high content of trace elements in the soil does not necessarily reflect their high concentration in cultures.

Murtaza et al. (2008) have found that cultivated plants in soils, consisting of a content of $\mathrm{Cd}$ inferior to the threshold values, may accumulate this metal with a very important concentrations exceeding the allowed levels.

According to Kabata-Pendias (2004), the soil-plant transfer of trace elements involves the interaction of many parameters: the plants features, features of the soil, the nature of contamination and the environmental facts,etc...

\section{Conclusion}

In developing countries, fields and gardens bordering the different conurbations are irrigated with urban wastewater containing relatively weak trace elements content. However, it is the long term (continuous) irrigation using wastewater that causes the accumulation of these toxic metals. Accumulation takes place in the surface horizon of the soil and is responsible for plants and animals metabolic disorders and hence contaminating the foodchains.

Despite the varying dangerous risks on health and environment, direct or indirect use of wastewater in agricultural irrigation in many developing countries is still planned.

Also, despite the general low concentration of trace elements in the treated effluents, the impact of this water ;however,remains a major concern to the environment. Since trace elements generally accumulate in the soil, and because of the biochemical conditions, they pass into the soil solution. They are more or less absorbed by plants and affect the quality of the agricultural products intended for both humans and animals which causes serious health problems.

This review was conducted to demonstrate the effect of trace elements resulting from wastewater irrigation and their contamination of soils and plants which represent not only a significant environmental risk, but also a potential health risk. 


\section{References:}

1. Adams, M. L., Zhao, F. J., McGrath, S. P., Nicholson, F. A., \& Chambers, B. J. (2004). Predicting cadmium concentrations in wheat and barley grain using soil properties. Journal of Environmental Quality, 33(2), 532-541.

2. Adriano, D. C., Wenzel, W. W., Vangronsveld, J., \& Bolan, N. S. (2004). Role of assisted natural remediation in environmental cleanup. Geoderma, 122(2-4), 121-142.

3. Agassi, M., Tarchitzky, J., Keren, R., Chen, Y., Goldstein, D., \& Fizik, E. (2003). Effects of prolonged irrigation with treated municipal effluent on runoff rate. Journal of environmental quality, 32(3), 10531057.

4. Alloway, B. J. (1995). Soil processes and the behavior of metals. Heavy metals in soils, 2, 11-37.

5. Al-Nakshabandi, G. A., Saqqar, M. M., Shatanawi, M. R., Fayyad, M., \& Al-Horani, H. (1997). Some environmental problems associated with the use of treated wastewater for irrigation in Jordan. Agricultural Water Management, 34(1), 81-94.

6. Arshad, M. A., \& Coen, G. M. (1992). Characterization of soil quality: physical and chemical criteria. American Journal of Alternative Agriculture, 7(1-2), 25-31.

7. Assadian, N. W., Esparza, L. C., Fenn, L. B., Ali, A. S., Miyamoto, S., Figueroa, U. V., \& Warrick, A. W. (1998). Spatial variability of heavy metals in irrigated alfalfa fields in the upper Rio Grande River basin. Agricultural water management, 36(2), 141-156.

8. Ayers, R. S., \& Westcot, D. W. (1994). FAO irrigation and drainage paper. Water quality for agriculture, (29), 156. http://www.fao.org/DOCREP/003/T0234E/T0234E00.HTM.

9. Bahri, A. (1999). Agricultural reuse of wastewater and global water management. Water Science and Technology, 40(4-5), 339-346.

10. Biggs, T. W., \& Jiang, B. (2009). Soil salinity and exchangeable cations in a wastewater irrigated area, India. Journal of environmental quality, 38(3), 887-896.

11. Cebula, J. (1980). Contents of some trace elements in soil irrigated with municipal wastewater. Environmental Protection Engineering, 6, 146-151.

12. Chary, N. S., Kamala, C. T., \& Raj, D. S. S. (2008). Assessing risk of heavy metals from consuming food grown on sewage irrigated soils and food chain transfer. Ecotoxicology and environmental safety, 69(3), 513-524. 
13. Chen, Z., He, M., Sakurai, K., Kang, Y., \& Iwasaki, K. (2007). Concentrations and chemical forms of heavy metals in urban soils of Shanghai, China. Soil Science \& Plant Nutrition, 53(4), 517-529.

14. Dère, C. (2006). Mobilité et redistribution à long terme des éléments traces métalliques exogènes dans les sols: Application à des Luvisols pollués par 100 ans d'épandage d'eaux usées brutes dans la plaine de Pierrelaye (Doctoral dissertation, ENGREF (AgroParisTech)).

15. Duan, R., Sheppard, C. D., \& Fedler, C. B. (2010). Short-term effects of wastewater land application on soil chemical properties. Water, Air, \& Soil Pollution, 211(1-4), 165-176.

16. Eriksson, J. E. (1989). The influence of $\mathrm{pH}$, soil type and time on adsorbtion and uptake by plants of $\mathrm{Cd}$ added to the soil. Water, Air, and Soil Pollution, 48(3-4), 317-335.

17. Faby, J. A., \& Brissaud, F. (1997). L'utilisation des eaux usées épurées en irrigation. Office International de l'eau, 76.

18. Flores, L., Blas, G., Hernandez, G., \& Alcala, R. (1997). Distribution and sequential extraction of some heavy metals from soils irrigated with wastewater from Mexico City. Water, Air, and Soil Pollution, 98(1-2), 105-117.

19. Gurel, M., Iskender, G., Ovez, S., Arslan-Alaton, I., Tanik, A., \& Orhon, D. (2007). A global overview of treated wastewater guidelines and standards for agricultural reuse. Fresenius Environmental Bulletin, 16(6), 590-595.

20. Hamilton, A. J., Stagnitti, F., Xiong, X., Kreidl, S. L., Benke, K. K., \& Maher, P. (2007). Wastewater irrigation: the state of play. Vadose zone journal, 6(4), 823-840.

21. He, Z. L., Yang, X. E., \& Stoffella, P. J. (2005). Trace elements in agroecosystems and impacts on the environment. Journal of trace elements in medicine and biology, 19(2-3), 125-140.

22. Ingwersen, J., \& Streck, T. (2005). A regional-scale study on the crop uptake of cadmium from sandy soils. Journal of Environmental Quality, 34(3), 1026-1035.

23. Jiries, A. G., Al Nasir, F. M., \& Beese, F. (2002). Pesticide and heavy metals residue in wastewater, soil and plants in wastewater disposal site near Al-Lajoun Valley, Karak/Jordan. Water, air, and soil pollution, 133(1-4), 97-107.

24. Juste, C., Chassin, P., Gomez, A., Linères, M., Mocquot, B., Feix, I., \& Wiart, J. (1995). Les micro-polluants métalliques dans les boues résiduaires des stations d'épuration urbaines. In Convention Ademe/INRA.

25. Kabata-Pendias, A. (2004). Soil-plant transfer of trace elements-an environmental issue. Geoderma, 122(2-4), 143-149. 
26. Khan, S., Cao, Q., Zheng, Y. M., Huang, Y. Z., \& Zhu, Y. G. (2008). Health risks of heavy metals in contaminated soils and food crops irrigated with wastewater in Beijing, China. Environmental pollution, 152(3), 686-692.

27. Kiziloglu, F. M., Turan, M., Sahin, U., Kuslu, Y., \& Dursun, A. (2008). Effects of untreated and treated wastewater irrigation on some chemical properties of cauliflower (Brassica olerecea L. var. botrytis) and red cabbage (Brassica olerecea L. var. rubra) grown on calcareous soil in Turkey. Agricultural water management, 95(6), 716-724.

28. Li, F., Okazaki, M., \& Zhou, Q. (2003). Evaluation of Cd uptake by plants estimated from total soil $\mathrm{Cd}, \mathrm{pH}$, and organic matter. Bulletin of environmental contamination and toxicology, 71(4), 0714-0721.

29. Liu, W. H., Zhao, J. Z., Ouyang, Z. Y., Söderlund, L., \& Liu, G. H. (2005). Impacts of sewage irrigation on heavy metal distribution and contamination in Beijing, China. Environment International, 31(6), 805-812.

30. Lucho-Constantino, C. A., Prieto-García, F., Del Razo, L. M., Rodríguez-Vázquez, R., \& Poggi-Varaldo, H. M. (2005). Chemical fractionation of boron and heavy metals in soils irrigated with wastewater in central Mexico. Agriculture, ecosystems \& environment, 108(1), 57-71.

31. Madyiwa, S., Chimbari, M., Nyamangara, J., \& Bangira, C. (2002). Cumulative effects of sewage sludge and effluent mixture application on soil properties of a sandy soil under a mixture of star and kikuyu grasses in Zimbabwe. Physics and Chemistry of the Earth, Parts $A / B / C, 27(11-22), 747-753$.

32. Mapanda, F., Mangwayana, E. N., Nyamangara, J., \& Giller, K. E. (2007). Uptake of heavy metals by vegetables irrigated using wastewater and the subsequent risks in Harare, Zimbabwe. Physics and Chemistry of the Earth, Parts A/B/C, 32(15-18), 1399-1405.

33. McGrath, S. P., Chang, A. C., Page, A. L., \& Witter, E. (1994). Land application of sewage sludge: scientific perspectives of heavy metal loading limits in Europe and the United States. Environmental Reviews, 2(1), 108-118.

34. Murtaza, G., Ghafoor, A., \& Qadir, M. (2008). Accumulation and implications of cadmium, cobalt and manganese in soils and vegetables irrigated with city effluent. Journal of the Science of Food and Agriculture, 88(1), 100-107.

35. Pescod, M. B. (1992). Wastewater treatment and use in agricultureFAO irrigation and drainage paper 47: Food and Agriculture Organization of the United Nations. Natural Resources Management 
and Environment Department. http://www. fao. org/docrep/T0551E/t0551e06. htm, 4.

36. Qishlaqi, A., \& Moore, F. (2007). Statistical analysis of accumulation and sources of heavy metals occurrence in agricultural soils of Khoshk River Banks, Shiraz, Iran. Am Eurasian J Agric Environ Sci, 2, 565573.

37. Qishlaqi, A., Moore, F., \& Forghani, G. (2008). Impact of untreated wastewater irrigation on soils and crops in Shiraz suburban area, SW Iran. Environmental monitoring and assessment, 141(1-3), 257-273.

38. Ramirez-Fuentes, E., Lucho-Constantino, C., Escamilla-Silva, E., \& Dendooven, L. (2002). Characteristics, and carbon and nitrogen dynamics in soil irrigated with wastewater for different lengths of time. Bioresource Technology, 85(2), 179-187.

39. Raschid-Sally, L., \& Jayakody, P. (2009). Drivers and characteristics of wastewater agriculture in developing countries: Results from a global assessment (Vol. 127).

40. Raschid-Sally, L., Carr, R., \& Buechler, S. (2005). Managing wastewater agriculture to improve livelihoods and environmental quality in poor countries. Irrigation and Drainage, 54(S1).

41. Rattan, R. K., Datta, S. P., Chhonkar, P. K., Suribabu, K., \& Singh, A. K. (2005). Long-term impact of irrigation with sewage effluents on heavy metal content in soils, crops and groundwater-a case study. Agriculture, Ecosystems \& Environment, 109(3-4), 310-322.

42. Scott, C. A., Faruqui, N. I., \& Raschid-Sally, L. (Eds.). (2004). Wastewater use in irrigated agriculture: Confronting the livelihood and environmental realities. CABI. www.idrc.ca/en/ev-31595-201-1DO TOPIC.html.

43. Shahalam, A., Zahra, B. M. A., \& Jaradat, A. (1998). Wastewater irrigation effect on soil, crop and environment: a pilot scale study at Irbid, Jordan. Water, Air, and Soil Pollution, 106(3-4), 425-445.

44. Sharma, R. K., Agrawal, M., \& Marshall, F. (2007). Heavy metal contamination of soil and vegetables in suburban areas of Varanasi, India. Ecotoxicology and environmental safety, 66(2), 258-266.

45. Schalscha, B. E., \& Ahumada, T. I. (1998). Heavy metals in rivers and soils of central Chile. Water Science and Technology, 37(8), 251-255.

46. Schirado, T., Vergara, I., Schalscha, E. B., \& Pratt, P. F. (1986). Evidence for Movement of Heavy Metals in a Soil Irrigated with Untreated Wastewater 1. Journal of Environmental Quality, 15(1), 912.

47. Sinha, S., Gupta, A.K., Bhatt, K., Pandey, K., Rai, U.N., \& Singh, K. P. (2006) distribution of metals in the edible plants grown at jajmau, kanpur (india) receiving treated tannery wastewater: relation with 
physico-chemical properties of the soil. Environmental Monitoring and Assessment 115: 1-22.

48. Smit, J., \& Nasr, J. (1992). Urban agriculture for sustainable cities: using wastes and idle land and water bodies as resources. Environment and urbanization, 4(2), 141-152.

49. Smith, C. J., Hopmans, P., \&. Cook, F. J. (1996) Accumulation of Cr, $\mathrm{Pb}, \mathrm{Cu}, \mathrm{Ni}, \mathrm{Zn}$ and $\mathrm{Cd}$ in soil following irrigation with treated urban effluent in Australia. Environmental Pollution, 94 (3) : 317323.

50. Solıs, C., Andrade, E., Mireles, A., Reyes-Solis, I.E., Garcia-Calderon, N., Lagunas-Solar, M.C., Pina, C.U., \& Flocchini, R.G. (2005). Distribution of heavy metals in plants cultivated with wastewater irrigated soils during different periods of time. Nuclear Instruments and Methods in Physics Research B 241: 351-355.

51. Thebo, A. L., Drechsel, P., Lambin, E. F., \& Nelson, K. L. (2017). A global, spatially-explicit assessment of irrigated croplands influenced by urban wastewater flows. Environmental Research Letters, 12(7), 074008.

52. UNEP (2005). Water and Wastewater Reuse. Environmentatly Sound Approach for Sustainable Urban Water Management.

53. Wu, G. H., \& Cao, S. S. (2010). Mercury and cadmium contamination of irrigation water, sediment, soil and shallow groundwater in a wastewater-irrigated field in Tianjin, China. Bulletin of environmental contamination and toxicology, 84(3), 336-341.

54. Xiong, X., Stagnitti, F., Peterson, J., Allinson, G., \& Turoczy, N. (2001). Heavy metal contamination of pasture soils by irrigated municipal sewage. Bulletin of environmental contamination and toxicology, 67(4), 535-540.

55. Xue, Q., \& Harrison, H. C. (1991). Effect of soil zinc, pH, and cultivar on cadmium uptake in leaf lettuce (Lactuca sativa L. var. crispa). Communications in soil science and plant analysis, 22(9-10), 975-991.

56. Yadav, R.K., Goyal, B., Sharma, R.K., Dubey, S.K., \& Minhas, P.S. (2002) Post-irrigation impact of domestic sewage effluent on composition of soils, crops and ground water-A case study. Environment International. 28: 481- 486. 